\title{
Religion and Depression in South Korea: A Comparison between Buddhism, Protestantism, and Roman Catholicism
}

\author{
Jinhee Seomun ${ }^{1}$, Junghyun Park ${ }^{2}$, Zong Woo Geem ${ }^{3}$ (iD and Hae-Jeung Lee ${ }^{2,4, *}$ \\ 1 Department of Health \& Welfare, Joongbu University, 201 Daehak Ro, Geumsan 31713, Korea; \\ jhseomun@joongbu.ac.kr \\ 2 Institute for Aging and Clinical Nutrition Research, Gachon University, 1342 Seongnam Daero, \\ Seongnam 13120, Korea; dkwls2784@gc.gachon.ac.kr \\ 3 College of Information Technology, Gachon University, 1342 Seongnam Daero, Seongnam 13120, Korea; \\ zwgeem@gmail.com \\ 4 Department of Food and Nutrition, Gachon University, 1342 Seongnam Daero, Seongnam 13120, Korea \\ * Correspondence: skysea1010@gmail.com or skysea@gachon.ac.kr; Tel.: +82-31-750-5968
}

Received: 1 July 2017; Accepted: 18 December 2017; Published: 22 December 2017

\begin{abstract}
Over the past few years, the occurrence of depression in South Korea has significantly increased. Even though Buddhism was the main religion in historical South Korea, Christianity has recently emerged as a dominant faith tradition. However, the relationship between religion and depression among older Korean adults is understudied. The present study is designed to investigate religious variations and the role of religious participation in depression among older Korean adults using the Korean Longitudinal Study of Aging (KLoSA). From the KLoSA database, 6817 participants were extracted and analyzed. Utilizing the Korean version of the 10-item Center for Epidemiological Studies-Depression Scale (CES-D 10) and the generalized linear models (GLM), a significant difference in depressive symptoms between religious groups $(p<0.05)$ and religious nones surfaced. This significant difference remained even after adjusting for the confounding factors. When the levels of depressive symptoms were compared across various faith traditions, the lowest depression score was detected from Buddhists (7.04), followed by Roman Catholics (7.12), and Protestants (7.71). Moreover, a significant difference in depressive symptoms between Buddhists and Protestants was observed. With regard to the frequency of religious participation, a significant difference in the depression score was observed only for Protestants. That is, the depression score for those who reported attending religious meetings 'once to six times a year' was significantly higher than the others. It is concluded that those who are religiously involved had significantly less depression symptoms than religious nones. Moreover, of the three faith traditions, Buddhists and Protestants showed a significant difference in depressive symptoms.
\end{abstract}

Keywords: depression; religion; religious affiliations; frequency of religious attendance; South Korea

\section{Introduction}

Depression is defined as a common, but serious medical illness and is known to negatively influence the individual's mental status and performance, such as emotion, cognitive performance, and decision making (American Psychiatric Association APA). Depression can lead to various physical, mental, and social problems (Charney et al. 2003; Bishwajit et al. 2017; Jung et al. 2017) and can reduce the quality of life, especially in older adults (Jung et al. 2017). As such, depression has become a worldwide public health concern (Bishwajit et al. 2017).

The past few decades have witnessed a growing body of research on the beneficial effects of religion on mental disorders, especially the depressive symptoms. According to a study by Koenig 
and his colleagues, 61 percent of previous studies (443 studies) reported that religion and spirituality were associated with a remission of depression (Koenig et al. 2012). In South Korea, the lifetime prevalence of depression has also increased from $4.0 \%$ in 2001 to $5.6 \%$ in 2006, and to $6.7 \%$ in 2011 (Ministry of Health and Welfare MHW). Although religion still has a significant impact on society in South Korea (Kim 2002a), religious variations in mental health remain unknown (Park et al. 2012b). Given this research paucity, the overall aim of this study is to investigate the relationship between religion and mental health, especially depressive symptoms, among older South Korean adults. It will first compare the depression scores between religious and non-religious respondents. Secondly, it will examine the differences in depressive symptoms across the three faith traditions in South Korea, namely, Buddhism, Protestantism, and Roman Catholicism. And finally, it will investigate the relationship between the frequency of religious attendance and depressive symptoms within each religious group using the nationally representative KLoSA dataset.

\section{Literature Review}

\subsection{Religious Denominations and Their Characteristics in South Korea}

In Western countries the primary religion is Christianity. By contrast, religious diversity is one of the significant characteristics of South Korea (Kim 2002a). According to statistics published in 2015, the percentage of people without religion was $56 \%$, and $44 \%$ of the Korean population identified themselves as being religious. However, the percentage of older adults with a religion was greater than the average of the South Korean population: $57.7 \%$ for $60-69$ years of age, and $58.2 \%$ for those who were above 70 in 2015. Among all the religious denominations in South Korea, Protestantism is the most popular religion (19.7\% of the population), followed by Buddhism (15.5\%), and Roman Catholicism $(7.9 \%)$ (Korea 2016). The proportion of atheists is substantial in Korean society (Park et al. 2012b). Therefore, various faith traditions coexist in contemporary South Korea due to unique historical and cultural contexts.

Of the three major religions in South Korea, Buddhism came from China to Korea in 372 A.D. It spread rapidly throughout Korea, and is now the oldest religion in the country. By contrast, Roman Catholicism and Protestantism were not introduced until the late 18th (1784) and 19th centuries, respectively. Protestant missionaries contributed to the country's industrialization and socio-economic development in general and to the establishment of modern schools in particular (Min 2014). At the same time, Christianity was mushroomed. Over time, Christian believers have increased in number and the Korean church has experienced remarkable growth. Most Korean churches run organized meetings with colleagues or families and encourage each other to attend church and be faithful (Kwon et al. 1997). Based on a survey with the help of Gallup Korea, the offering amounts from the Protestant churches were larger than other religious groups in Korea (Han 2005). However, one report stated that faithfulness to the church decreased due to the burden of church offerings (Kim 2005).

While the Protestant churches are located in the urban areas, Buddhist temples are mostly situated in the mountains away from central cities. Even if Buddhist temples were relocated to improve their accessibility, the number of Buddhist temples would still remain small as compared to the Protestant churches (Kim 2002a; Kim 2002b). Buddhist teachings and philosophy provide the foundation for such practices as meditation and mindfulness-based cognitive therapy as a psychiatric treatment (Helmes and Ward 2017). To our best knowledge, there has been no report on organized meetings among Korean Buddhists that are reminiscent of Korean Protestants.

Although Christianity—including Protestantism and Roman Catholicism-centers on the life and teachings of Jesus Christ, Korean Protestant churches tend to be egocentric and disrespectful of other religious groups in aggressive missions (Kim 2016). Korean Protestantism has a heavily evangelical orientation, which focuses on missionary activities with seemingly little interest in social concerns. The aggressive and sometimes antagonistic evangelical activities of diehard Protestants against the 
other religious groups in Korea have alienated many Koreans from Protestantism (Min 2014). On the other hand, Buddhism recognizes and accepts other faith traditions.

Compared to active and passionate Protestantism, Roman Catholicism has relatively meditative and philosophical activities that are more similar to Buddhism's religious practices. Christianity emphasizes religious participation especially attendance at Sunday worship services, whereas other religious traditions in South Korea do not (You et al. 2009). Furthermore, the major religious traditions in Korea have influenced each other and been influenced by Korean traditional religions, such as Shamanism and Confucianism (Kim 2002a).

\subsection{Religious Affiliations, Depression, and Mental Health}

The protective effects of religion on public health have been well documented in recent decades. Since religion signifies social/emotional support, cognitive schema, and/or spiritual beliefs (Al-Kandari 2011; Seomun 2010), religion can enhance the capacity of an individual to cope with a variety of stresses arising from adverse life events, such as illness, relationship dissolution, and the death of a close relative (Koenig 2009; McFarland 2010; Park et al. 2012a). Thus, religious support can reduce levels of depression and increase life satisfaction (Braam et al. 2001; Park et al. 2012a). A review on the role of religion in mental health reported that two-thirds of 93 observational studies had discovered significantly lower rates or symptoms of depressive disorders among religious people (Koenig 2009). In particular, empirical studies have documented the protective role of religion in the mental health of the geriatric population (Braam et al. 2001; Jung et al. 2017). For example, studies revealed that religious involvement, faith, and practice showed beneficial effects on psychological well-being among older adults (O'Connor and Vallerand 1990; Levin and Chatters 1998).

Although a number of studies have indicated the beneficial effects of religion on mental health, religious or denominational variations in the mental health of older adults in South Korea are under studied. One study reported that Catholics showed a higher prevalence of 'lifetime' and 'past' major depressive episodes, but not that of the last year (Park et al. 2012b). The same study suggested that certain individuals might become a Catholic to reduce their depressive symptoms as they assumed that Catholic beliefs could provide positive effects on mental health. On the other hand, Protestants reported a higher prevalence of lifetime anxiety disorders and a lower prevalence of lifetime alcohol use disorder. The lower prevalence of alcohol disorder among Protestants was not surprising as the Korean Protestants tend to restrain alcohol consumption and smoking in comparison to the Korean Catholics, which do not (Kim and Park 2000; Park et al. 2012b).

As to the older Korean Protestants, one study indicated that those who had been consistently identified as religious reported lower levels of depressive symptoms (Kang and Cho 2013). It seems that being religious over time may facilitate participation in more frequent and multiple forms of religious activities, thus, developing positive attitudes. Regarding the denominational variation in depressive symptoms in South Korea, previous studies have described the unique characteristics of various religious traditions, including faith, belief, and frequency of religious participation. With these general research findings in mind, this study focuses on the relationship between frequency of religious attendance and depressive symptoms within and across religious denominations.

\section{Methods}

\subsection{Data}

This study used data from the 5th Korean Longitudinal Study of Ageing (KLoSA) conducted in 2015. The Korea Employment Information Service carried out this survey to identify the aging process in the Korean population for policy development and academic research. The sampling frame of KLoSA was comprised of enumeration districts (EDs) as identified by the 2005 Population and Housing Census (the National Statistical Office). The 5th KLoSA was initiated on 1 September 2014 for the aging panel nationwide and ended on 30 November 2014. The survey was conducted using a 
laptop for Computer Assisted Personal Interviewing (CAPI), and was equipped with references to the participant's basic information, including name, year of birth, gender, and address.

\subsection{Respondents}

This study included data of 7029 young old adults ages between 53 and 64 years from the 5 th KLoSA survey. Respondents who belonged to Won Buddhism $(n=14)$ and other religions $(n=30)$, and who reported to take any psychiatric treatments/drugs $(n=165)$ were excluded. In addition, three respondents with missing data were also excluded, thus giving rise to an analytical sample of 6817 respondents. Furthermore, there were 1154 respondents who reported the frequency of attendance at religious meetings. Five of these respondents who reported having no religion were excluded. Therefore, the final sub-sample for the analysis of attendance at regular religious meetings was 1149 .

\subsection{Independent Variables}

Religion variables came from several survey questions in the 5th KLoSA (see Appendix B). Respondents were first asked, "Do you believe in any religion? If you do, what kind of religion do you believe in?" Response options were: no religion, Protestantism, Roman Catholicism, Buddhism, Won Buddhism (omitted from this study), and other religions (omitted from this study). The second question gauged religious participation. Respondents were asked, "Do you attend any meeting?" The response categories included: religious meeting, meeting for friendship, meetings for leisure/culture/sports, alumni association/hometown alumni/gathering, volunteer groups, political party/civic group/profitable group, others, and no meeting. If the respondents reported "Religious meeting", they were then asked, "How often do you go to the meeting?" Although there were eight response categories, to ensure sufficient sample size in each category these eight categories were collapsed into four with 1 = over 2-4 times a week, 2 = once a week, $3=$ once or twice a month, and $4=$ once to six times a year.

\subsection{Dependent Variable}

To evaluate levels of depression, this study used the Korean version of the Center for Epidemiologic Studies Depression Scale 10 (CES-D 10), a short form of the CES-D (Radloff 1977) (see Appendix A). Although the original CES-D consists of 20 items, a short form (only 10 items) was developed to relieve the older adults of the burden to respond. The reliability of the CES-D 10 has been proven to be similar to the original CES-D. The CES-D 10 was completed by rating items for frequency of mood or feelings during the past week on a four-point scale, ranging from zero ("never") to three ("most of the time"). Higher scores in the depression scale represented higher levels of depressed mood, and the scale ranged from 0 to 30. The reliability coefficient (Cronbach's $\alpha$ ) of the depression scale was 0.887 .

\subsection{Covariates}

The confounding factors, age, gender, education, the presence of a spouse, self-health status, income, and activities of daily living (ADL) were adjusted. Among the covariates, age, income and ADL were continuous variables, whereas the rest were categorical variables. Educational levels ( $\leq 6$ years, 9 years, 12 years, and $\geq 14$ years) and the presence of spouse (yes/no) were provided by the Korea Employment Information Service. The spouse variable included those who were divorced, bereaved, and unmarried. Self-health status was used as a confounding factor (McFarland 2010) and grouped into one of the five available categories: very good, good, normal, poor, and very poor. The self-health status question asked respondents how healthy they were currently. Household income reflected the gross income of all household members during the past year. ADL referred to the ability to perform everyday activities including changing clothes, washing face/brushing teeth/washing hair, taking a bath/shower, eating a meal, going out of a room, using the toilet, and urinary/fecal continence. 
If some or complete help was needed with ADL, the score was set at ' 1 ', otherwise, the score was set at ' 0 '. All the basic activities of daily living were then combined and indexed as a composite ADL variable. The index scores ranged from 0 to 7 .

\subsection{Statistical Modeling}

To evaluate religious variations in depressive symptoms, three multiple linear regression models were estimated to predict the CES-D 10 scores. The coefficients of the religion dummy variables were compared to religious nones that served as a reference. First, Model 1 was adjusted for age and gender. Model 2 was adjusted for additional covariates including income and education (SES). Model 3 was adjusted for all covariates: age, gender, income, education, ADL, the presence of a spouse, and self-health status. In addition, the generalized linear model (GLM) was used to assess the difference in depressive symptoms among religious groups as well as religious nones and the frequency of attendance at religious meetings. The GLM analysis was also adjusted for covariates that could influence depressive symptoms. The adjusted means were used to examine religious variations in depressive symptoms and in the frequency of religious participation within each religious group (SAS 1999). The PDIFF option was used to compute $\mathrm{p}$ values for all possible significance between the groups (Hsu 1996). Statistical significance was set at $p<0.05$ and all data were presented as mean \pm standard error (SE). SAS software, version 9.3, was used to analyze all data for this study.

\section{Results}

\subsection{Sample Characteristics}

Table 1 shows the respondent's characteristics with or without a religion. As shown in the table, the total number of respondents for this study was 6817. The number of respondents without a religion was 3857 (56.6\%). Among 2960 religious respondents, there were 1290 (18.9\%) Buddhists, 1237 (18.1\%) Protestants, and 433 (6.4\%) Roman Catholics. As displayed in the table, the average age was younger for respondents without a religion (64.7 years old) than those with a religious affiliation. While the Korean Buddhists reported the lowest average household income (28.61 million Korean Won), their Roman Catholic counterparts reported the highest (36.75 million Korean Won). The Roman Catholic respondents also reported the lowest ADL score (0.07) whereas religious nones showed the highest ADL score (0.16). The highest depression scores came from religious nones (6.75), and the lowest scores were observed from the Roman Catholic respondents (5.20). Of 6817 respondents, $53.8 \%$ (3902) were female. The proportion of male respondents without a religious affiliation was $54.4 \%$. The proportion of female with a religious affiliation was higher (64.6\%) when compared to religious nones $(45.6 \%)$, while the depression score was lower (5.73) for those with a religious affiliation than those without a religious affiliation (6.75). In terms of educational attainment, $35.4 \%$ of the respondents reported that they had less than 6 years of education, which is the largest category, followed by 12 years, 9 years, and 14 years or more. Moreover, the table shows that $18.6 \%$ of the Protestant respondents were college educated whereas $44.5 \%$ of the Buddhist respondents had less than 6 years of education. Turning to the presence of a spouse, $77.5 \%$ of the respondents reported having a spouse. Religious nones showed the highest percentage of having a spouse (77.9\%). For the self-reported health status, the respondents who answered 'very good', 'good', 'normal', 'poor', and 'very poor' were 1.0\%, $31.9 \%, 44.0 \%, 18.6 \%$, and $4.5 \%$, respectively. The highest percentage of 'good' was reported by the Roman Catholic respondents $(34.8 \%)$, and the highest percentage 'poor' came from the Buddhist respondents $(21.6 \%)$. 
Table 1. Respondents' characteristics with/without religion.

\begin{tabular}{|c|c|c|c|c|c|c|}
\hline & $\begin{array}{c}\text { Total } \\
N=6817\end{array}$ & $\begin{array}{c}\text { No Religion } \\
N=3857\end{array}$ & $\begin{array}{l}\text { Religion } \\
N=2960\end{array}$ & $\begin{array}{l}\text { Buddhism } \\
N=1290\end{array}$ & $\begin{array}{c}\text { Protestantism } \\
\quad N=1237\end{array}$ & $\begin{array}{c}\text { Roman Catholicism } \\
\qquad N=433\end{array}$ \\
\hline Age, mean \pm SE & $65.01 \pm 0.11$ & $64.70 \pm 0.15$ & $65.42 \pm 0.17$ & $65.84 \pm 0.25$ & $65.05 \pm 0.27$ & $65.36 \pm 0.45$ \\
\hline Income ${ }^{1}$, mean $\pm \mathrm{SE}$ & $3101.43 \pm 33.03$ & $3138.43 \pm 42.64$ & $3051.90 \pm 50.51$ & $2861.62 \pm 75.58$ & $3015.72 \pm 69.69$ & $3674.99 \pm 186.27$ \\
\hline $\mathrm{ADL}^{2}$, mean $\pm \mathrm{SE}$ & $0.14 \pm 0.01$ & $0.16 \pm 0.02$ & $0.10 \pm 0.02$ & $0.10 \pm 0.02$ & $0.11 \pm 0.02$ & $0.07 \pm 0.03$ \\
\hline Depression, mean $\pm \mathrm{SE}$ & $6.31 \pm 0.06$ & $6.75 \pm 0.08$ & $5.73 \pm 0.09$ & $5.52 \pm 0.14$ & $6.11 \pm 0.15$ & $5.20 \pm 0.24$ \\
\hline \multicolumn{7}{|c|}{ Gender (weighted \%) } \\
\hline male & $2915(46.23)$ & $1950(54.37)$ & $965(35.34)$ & $372(32.19)$ & $440(37.91)$ & $153(36.47)$ \\
\hline female & $3902(53.77)$ & $1907(45.63)$ & $1995(64.66)$ & $918(67.81)$ & 797 (62.09) & $280(63.53)$ \\
\hline \multicolumn{7}{|c|}{ Education (weighted \%) } \\
\hline$\leq 6$ years & $3074(35.44)$ & $1747(35.45)$ & $1327(35.44)$ & $673(44.50)$ & $503(30.47)$ & $151(25.09)$ \\
\hline 9 years & 1147 (17.29) & $627(16.80)$ & $520(17.94)$ & $242(19.58)$ & $217(17.76)$ & $61(13.96)$ \\
\hline 12 years & $1901(33.72)$ & $1102(34.49)$ & 799 (32.69) & $304(28.49)$ & $335(33.18)$ & $160(42.77)$ \\
\hline$\geq 14$ years & $695(13.55)$ & $381(13.26)$ & $314(13.94)$ & $71(7.43)$ & $182(18.59)$ & $61(18.18)$ \\
\hline \multicolumn{7}{|c|}{ Presence of spouse (weighted \%) } \\
\hline yes & $5152(77.50)$ & $2957(77.92)$ & $2195(76.93)$ & $970(77.70)$ & $900(76.15)$ & $325(77.10)$ \\
\hline no & $1665(22.50)$ & $900(22.08)$ & $765(23.07)$ & $320(22.30)$ & $337(23.85)$ & $108(22.90)$ \\
\hline \multicolumn{7}{|c|}{ Self-health status (weighted \%) } \\
\hline very good & $71(1.02)$ & $42(0.90)$ & $29(1.18)$ & $15(1.41)$ & $12(1.18)$ & $2(0.57)$ \\
\hline good & $1799(31.89)$ & $1057(32.92)$ & $742(30.52)$ & $312(29.47)$ & $307(30.03)$ & $123(34.83)$ \\
\hline normal & $3031(44.02)$ & $1718(44.32)$ & $1313(43.62)$ & $574(43.16)$ & $540(43.50)$ & $199(45.21)$ \\
\hline poor & $1525(18.59)$ & $807(17.16)$ & $718(20.5)$ & $320(21.56)$ & $308(20.83)$ & $90(16.59)$ \\
\hline very poor & $390(4.48)$ & $232(4.70)$ & $158(4.18)$ & $69(4.40)$ & $70(4.45)$ & $19(2.79)$ \\
\hline
\end{tabular}

${ }^{1}$ Income unit: 10,000 Korean Won; ${ }^{2}$ ADL: Activities of Daily Living. 


\subsection{Religious Variations in Depressive Symptoms}

Table 2 indicates the results of the coefficient estimate of each religion compared to non-religion. In comparison with the 'No-religion' group, all religious affiliations had significantly negative coefficient estimates with regards to the depression score for all models $(p<0.05)$.

Table 3 shows the average depression scores between respondents who are religious and those who are religious nones. A significant difference between these two groups was detected in all three models. In the age and gender adjusted model, the average depression scores were 7.30 for religious nones and 6.03 for those who are religious. The difference remained statistically significant in a multivariable-adjusted model, and the scores were 8.52 and 7.35, respectively.

Comparison of the average depressive symptoms across religious traditions is also shown in Table 3. In Model 1 that was adjusted for age and gender, the highest depression score (7.30) was observed for religious nones and the lowest score (5.51) came from the Catholic respondents. No significant difference in the depression scores surfaced between Buddhists and Catholics. After adjusting for SES (age, gender, income, and education levels), the pattern in the depression scores across various religious groups was similar to Model 1. In Model 3, which was a multivariable-adjusted model, the depression scores for Buddhists and Protestants were significantly different (7.04 and 7.71, respectively), but no significant difference emerged for Catholics (7.12) as compared to Buddhists and Protestants. Religious nones and Buddhists showed the highest (8.52) and lowest (7.04) depression scores, respectively. These results did not significantly change even after adjusting for other characteristics such as chronic disease (data not shown).

\subsection{Religious Attendance and Depressive Symptoms}

Table 4 displays the average depression scores by frequency of attendance at religious meetings after adjusting for relevant covariates. In Model 1, a significant difference in the average depression scores by frequency of attendance at religious meetings was detected only for Protestants. This significant difference was consistently observed in Model 2 that controlled for respondents' SES, and in Model 3 that adjusted for other covariates. In Model 3, the average depression score for those who reported they attended religious meetings frequently (e.g., once to 6 times a year) was significantly higher for Protestants (12.14). However, for the Buddhist and Roman Catholic respondents, the average depression scores did not significantly vary by frequency of attendance at religious meetings. 
Table 2. OLS regression coefficients of denominational affiliation to predict depressive symptoms.

\begin{tabular}{|c|c|c|c|c|c|c|c|c|c|c|c|c|c|c|c|}
\hline \multirow[b]{2}{*}{ Type of Religion } & \multicolumn{5}{|c|}{ 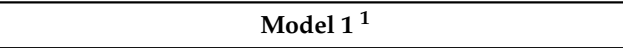 } & \multicolumn{5}{|c|}{ 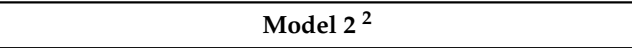 } & \multicolumn{5}{|c|}{ Model $3^{3}$} \\
\hline & Estimate & SE & $p$-Value & $\begin{array}{c}\text { Adj. } \\
\text { R-Square }\end{array}$ & F Value & Estimate & SE & $p$-Value & $\begin{array}{c}\text { Adj. } \\
\text { R-Square }\end{array}$ & F Value & Estimate & SE & $p$-Value & $\begin{array}{c}\text { Adj. } \\
\text { R-Square }\end{array}$ & F Value \\
\hline No Religion & \multicolumn{3}{|c|}{ Reference } & & & \multicolumn{3}{|c|}{ Reference } & & & \multicolumn{3}{|c|}{ Reference } & & \\
\hline Buddhism & -1.56 & 0.17 & $<0.0001$ & 0.08 & 114.05 & -1.61 & 0.16 & $<0.0001$ & 0.09 & 77.84 & -1.49 & 0.15 & $<0.0001$ & 0.20 & 95.79 \\
\hline Protestantism & -0.83 & 0.16 & $<0.0001$ & & & -0.85 & 0.16 & $<0.0001$ & & & -0.81 & 0.15 & $<0.0001$ & & \\
\hline Roman Catholicism & -1.79 & 0.25 & $<0.0001$ & & & -1.69 & 0.25 & $<0.0001$ & & & -1.40 & 0.24 & $<0.0001$ & & \\
\hline
\end{tabular}

1 Age and gender were adjusted for Model $1 ;{ }^{2}$ Age, gender, income, and education (SES) were adjusted for Model 2; ${ }^{3}$ Age, gender, income, ADL, education, presence of spouse, and self-health status were adjusted for Model 3. Coefficient estimates 'Religious affiliations' compared to 'No religion' as a reference were significantly different at $\alpha=0.05$ by multiple linear regression.

Table 3. Depressive symptoms by denominational affiliation.

\begin{tabular}{ccccc}
\hline \multirow{2}{*}{ Type of Religion } & \multirow{N}{*}{} & Model 1 & Model 2 $^{\mathbf{2}}$ & Model 3 $^{\mathbf{3}}$ \\
\cline { 3 - 5 } & & Lsmean \pm SE & Lsmean \pm SE $^{\text {Lsmean } \pm \text { SE }}$ \\
\hline No Religion & 3857 & $7.30^{\mathrm{c}} \pm 0.08$ & $7.41^{\mathrm{c}} \pm 0.09$ & $8.52^{\mathrm{c}} \pm 0.15^{*}$ \\
Religion & 2960 & $6.03^{*} \pm 0.09$ & $6.12^{*} \pm 0.10$ & $7.35^{*} \pm 0.15$ \\
Buddhism & 1290 & $5.74^{\mathrm{a}} \pm 0.14$ & $5.80^{\mathrm{a}} \pm 0.15$ & $7.04^{\mathrm{a}} \pm 0.18$ \\
Protestantism & 1237 & $6.48^{\mathrm{b}} \pm 0.14$ & $6.56^{\mathrm{b}} \pm 0.14$ & $7.71^{\mathrm{b}} \pm 0.18$ \\
Roman Catholicism & 433 & $5.51^{\mathrm{a}} \pm 0.24$ & $5.72^{\mathrm{a}} \pm 0.24$ & $7.12^{\mathrm{a}, \mathrm{b}} \pm 0.25$ \\
\hline
\end{tabular}

${ }^{1}$ Age and gender were adjusted for Model 1. ${ }^{2}$ Age, gender, income, and education (SES) were adjusted for Model 2. ${ }^{3}$ Age, gender, income, ADL, education, presence of spouse, and self-health status were adjusted for Model 3. * Lsmeans between 'No religion' and 'Religion' were significantly different at $\alpha=0.05$ by GLM/PDIFF. Lsmeans between 'No religion', 'Buddhism', 'Protestantism', and 'Roman Catholicism' were compared by GLM/PDIFF and present the differences with letters such as a, b, and c. Lsmeans in a column without a common letter were significantly different at $\alpha=0.05$. 
Table 4. Depressive symptoms by frequency of religious attendance and denominational affiliation.

\begin{tabular}{|c|c|c|c|c|c|}
\hline & \multirow{2}{*}{ Frequency } & \multirow{2}{*}{$N$} & Model $1^{1}$ & Model $2^{2}$ & Model $3^{3}$ \\
\hline & & & Lsmean $\pm \mathrm{SE}$ & Lsmean $\pm \mathrm{SE}$ & Lsmean $\pm \mathrm{SE}$ \\
\hline \multirow{4}{*}{ Buddhism $(n=138)$} & Over 2-4 times a week & 8 & $5.06^{\mathrm{NS}} \pm 1.41$ & $5.06^{\mathrm{NS}} \pm 1.44$ & $5.79^{\mathrm{NS}} \pm 1.65$ \\
\hline & Once a week & 18 & $4.86 \pm 0.78$ & $4.27 \pm 0.88$ & $4.78 \pm 1.27$ \\
\hline & Once or twice a month & 54 & $5.89 \pm 0.48$ & $5.31 \pm 0.58$ & $6.00 \pm 1.04$ \\
\hline & Once to 6 times a year & 58 & $6.15 \pm 0.51$ & $5.38 \pm 0.64$ & $5.74 \pm 1.13$ \\
\hline \multirow{4}{*}{ Protestantism $(n=781)$} & Over 2-4 times a week & 196 & $6.22^{\mathrm{a}} \pm 0.34$ & $6.19^{a} \pm 0.36$ & $7.54^{\mathrm{a}} \pm 0.51$ \\
\hline & Once a week & 475 & $6.20^{\mathrm{a}} \pm 0.23$ & $6.19^{a} \pm 0.24$ & $7.61^{\mathrm{a}} \pm 0.44$ \\
\hline & Once or twice a month & 96 & $5.61^{\mathrm{a}} \pm 0.47$ & $5.80^{\mathrm{a}} \pm 0.50$ & $7.31^{\mathrm{a}} \pm 0.60$ \\
\hline & Once to 6 times a year & 14 & $10.20^{\mathrm{b}} \pm 1.30$ & $10.71^{\mathrm{b}} \pm 1.30$ & $12.14^{\mathrm{b}} \pm 1.31$ \\
\hline \multirow{4}{*}{ Roman Catholicism $(n=230)$} & Over 2-4 times a week & 44 & $6.84^{\mathrm{NS}} \pm 0.76$ & $6.69^{\mathrm{NS}} \pm 0.81$ & $8.38^{\mathrm{NS}} \pm 1.30$ \\
\hline & Once a week & 143 & $6.14 \pm 0.39$ & $6.03 \pm 0.44$ & $7.56 \pm 1.12$ \\
\hline & Once or twice a month & 36 & $5.50 \pm 0.77$ & $5.24 \pm 0.80$ & $6.16 \pm 1.28$ \\
\hline & Once to 6 times a year & 7 & $6.52 \pm 1.73$ & $5.99 \pm 1.75$ & $6.01 \pm 2.03$ \\
\hline
\end{tabular}

${ }_{1}^{1}$ Age and gender were adjusted for Model 1. ${ }^{2}$ Age, gender, income, and education (SES) were adjusted for Model 2. ${ }^{3}$ Age, gender, income, ADL, education, presence of spouse, and self-health status were adjusted for Model 3. NS: Non-significant. Lsmeans in each column with different letters $(a, b)$ were significantly different at $\alpha=0.05$ by GLM/PDIFF. 


\section{Discussion}

Neurological disorder, especially depression, has become a serious global concern(Bishwajit et al. 2017) and is now known to be associated with the occurrence of various physical, mental, and social problems, especially in South Korea (Charney et al. 2003; Bishwajit et al. 2017; Jung et al. 2017). Although some studies have shown an association between religiosity and depressive symptoms, no study has reportedly investigated denominational or religious variations in depressive symptoms among older Korean adults. This study revealed that the average depression scores were statistically different between those who reported a religious affiliation and those who didn't report a religious affiliation and between Protestants and Buddhists.

\subsection{Population Characteristics and Depressive Symptoms}

There were more female respondents in all of the three religious groups, but not in the non-religious group. This could be due to: (1) Gendered socialization that encourages women to be passive and obedient; (2) Restricted personal relationships for women that can be formed and maintained in the religious community; and (3) Extensive social ties and social support systems that can be established in the church (McFarland 2010). Even though a number of studies have reported a stronger religious impact on women than men, the moderating role of gender on the association between religion and depression is inconclusive (McFarland 2010; Kralovec et al. 2017).

With regard to educational attainment cross religious traditions, this study showed that Protestants and Roman Catholics tended to be better educated than Buddhists. This is consistent with the previous report demonstrating that one-quarter of Protestants had a university degree or higher while just seven percent of Buddhists had a similar educational background (Kim 2002a). This pattern might be associated with the fact that Protestant missionaries established dozen of modern schools that helped their members obtain a better education (Min 2014).

Older adults are the most vulnerable with regard to mental illness. The occurrence of depression in this population may be caused by physical disabilities, low socio-economic status, and the death of a spouse or relative (Koenig et al. 1998; Hahn et al. 2004). As such, sex, age, marital status, education, job, monthly household income, and living with others have been consistently reported as social determinants of depression in the Korean population (Won et al. 2017). A prospective cohort study that evaluated risk and protective factors for late-life depression identified four groups of social determinants: demographic, social, lifestyle/behavioral, and health/medical. Studies conducted in South Korea reported that the main sources of stress among older Korean adults were health problems and diseases (Lee and Lee 2002; Jeon et al. 2016).

\subsection{Religious Variations in Depressive Symptoms}

Over the past decade or so, a growing body of evidence for the relationship between religion and mental health has emerged primarily from Western research (Braam et al. 2001; Koenig 2009). However, the context of religion in South Korea differs considerably from that of Western societies (Baker 2006); traditional religions including Shamanism, Confucianism, and Taoism have had an impact on modern Korean religious landscape (Kim 2002a; Kim 2008). Western countries are dominated by Christianity and several denominations, such as Roman Catholicism, Conservative Protestantism, and mainline Protestantism. Because of diverse religious traditions in South Korea, it is important to compare the results across various faith traditions. In this study, the lowest level of depressive symptoms was observed from the Buddhist respondents, a religion that is heavily linked to meditation and prayer. The second lowest level of depressive symptoms was observed from the Roman Catholic respondents, a religion that has monastic retreat programs. The differences in depression levels could be due to differences in treatment programs: meditation and mindfulness-based cognitive therapy (MBCT) versus clinical psychology (Kim et al. 2009; Helmes and Ward 2017; Maxwell and Duff 2016; Davidson 2016; Kuyken et al. 2016). 
Although Buddhists tend to exercise compassion for others, no research has been conducted to investigate relationship between religion-based social support and depression among older Korean Buddhists.

This study did not reveal a significant difference in depressive symptoms between the Buddhist and Roman Catholic respondents, or between the Protestant and Roman Catholic respondents. However, a significant difference in depression between Protestants and Buddhists was detected. Roman Catholics appeared to be similar to both Buddhists and Protestants. While Roman Catholicism and Protestantism share common ground in their fundamental religious roots (Kim 2002b), Catholicism and Buddhism also have similarities. For example, both Roman Catholicism and Buddhism place a high premium on peace, meditation, and the propagation of good deeds to further spiritual enlightenment, although one major difference exists; that is, Catholicism believes in an omnipresent God, while Buddhism does not.

This study revealed that the level of depressive symptoms was lowest for the Buddhist respondents and highest for the Protestant respondents. This religious difference is statistically significant. To our best knowledge, there have been few background studies to explain this difference in Korea. There are several practices that could help to understand the difference in depression between the Buddhist and Protestant older adults. Not only are Korean Protestants pressured to regularly attend church meetings every Sunday, they are also pressured to recruit and convert others to Protestantism as well (Min 2014). This fundamentalist idea and activity may increase their stress level. In contrast, Korean Buddhists tend to focus on prayer and meditation, which may explain why they have a lower level of depressive symptoms.

The key finding of religious variations in depressive symptoms was consistent with previous studies (Hodges 2002; Koenig 2009; Rasic et al. 2011; Behere et al. 2013). That is, religious nones reported a higher level of depressive symptoms than other religious groups. According to a review conducted by Koenig (2009), two-thirds of 93 observational studies revealed significantly lower proportions of depressive disorder or fewer depressive symptoms among religious people. Moreover, longitudinal studies indicated that greater religiousness predicted fewer depressive symptoms or faster remission of symptoms (Smith et al. 2003). For example, among eight randomized and controlled trials (RCTs) five studies showed that psychological interventions based on religion resulted in faster symptom improvement when compared to secular-based treatment (Koenig 2009). Studies also suggested that religion might function as a buffer against depressive symptoms. In fact, social support, religiousness, and spirituality were identified as the major traits of religion to relieve depression (Wink et al. 2005; Koenig and Büssing 2010). Although difference exists in the degree of social support, the majority of religions worldwide have the virtue of helping others (Krause et al. 1999), and non-institutionalized religious practices such as meditation and sacred connectedness with God or nature can serve as coping mechanisms (Wink et al. 2005). Previous studies indicated that religious participation played a significant role in achieving greater life satisfaction and improved psychological health. Religion can lead to lower incidences of psychiatric disorders (Chaaya et al. 2007; Ng et al. 2017). It was reported that public and private religious practices, including praying, confession, forgiveness, and blessings, could help one to maintain better mental health as these religious practices are known to help participants cope with fears, anxiety, frustration, anomie, despondency, and isolation (Behere et al. 2013). Such a religious effect has been especially noticeable in the aging population (Braam et al. 2001; McFarland 2010; Hayward et al. 2012; Park et al. 2012a).

Religion also played a significant role in mental health or psychological health in a geriatric population (Hahn et al. 2004). Social support may be the primary contributing factor to improve the quality of life in older adults (Penninx et al. 1997). Numerous studies have shown that strong social ties provide stressed older adults with more effective coping capabilities, and religion may provide more meaningful social support than secular social relationships for older adults (Krause et al. 1999; Krause 2006). According to previous research, as people age, they tend to become more selective in maintaining social relationships and prefer building strong connections with fewer people in their 
relationships, and the church may provide them with these kinds of relationships (Barna 2002). In the case of South Korea, most Protestant churches run organized small-group ministries, based on the age and gender of believers to study the Bible and to share their lives (Kwon et al. 1997). Korean Buddhism and Roman Catholicism, on the other hand, hold formal ceremonies or public worship services on a regular basis, but we were not able to confirm the organized social support system in those groups due to the lack of evidence.

\subsection{Depressive Symptoms and Frequency of Attendance at Religious Meetings}

Religiosity is a multidimensional construct that encompasses involvement in religious activities, intrinsic faith, belief, attitudes, practices, identification, and affiliation ( $\mathrm{Ng}$ et al. 2017). Church attendance is one of the most widely used measures to evaluate the extent of religious involvement (Behere et al. 2013). One European study showed that regular church attendance was negatively associated with the prevalence of depression (Braam et al. 2001), which was confirmed by another study demonstrating that more frequent participation in public worship services was associated with a lower level of depression (Hayward et al. 2012). Using attendance at religious meetings as an indicator of religious involvement or religiosity, no consistent results surfaced in this study. However, there was a statistically significant difference between those who attended more than once a month and those who attended sometimes. The frequency of attendance at regular religious meetings was not associated with depressive symptoms across various religious groups, which may be a reflection of religious characteristics in South Korea. For instance, Korean Protestants frequently attend church and regularly participate in small group meetings, which is a powerful social bonding amongst believers when compared with secular social support (Kwon et al. 1997; Alumkal 1999). On the other hand, Buddhism and Roman Catholicism in South Korea emphasize on private prayers.

Religious accessibility varies in South Korea. As noted previously, Korean Buddhism is marked by a lower level of geographical accessibility. In fact, Buddhist temples are mostly located in the mountains far away from central cities. Even if they were to be relocated, the number of Buddhist temples still remains low when compared to Protestant churches (Kim 2002a, 2002b). Thus, older and more enthusiastic Korean Buddhists often perform private prayers and meditation. This might be considered as one of the reasons for Korean Buddhists to report lowest level of depressive symptoms.

Roman Catholic churches are also geographically difficult for access due to the limited number of Roman Catholic churches (1100) as compared to Protestant churches that are located in residential areas in significant numbers (nearly 60,000 across South Korea) (Kim 2002b). Although statistically insignificant, a higher level of depressive symptoms was observed from the Catholic respondents who reported attending religious meetings over 2-4 times a week. One possible explanation for this observation may be that the depressed older Korean adults go to daily mass for healing purposes. However, more painstaking studies are warranted to understand the effects of attendance at religious meetings on depressive symptoms among different religious traditions. Moreover, easy access of Protestant churches may account for the different participation rate between the Protestant respondents and respondents in other religious traditions. Consistent with previous research (Li et al. 2016), this study showed that the highest level of depressive symptoms was in the category of occasional attendance.

\section{Conclusions}

There are several limitations in this study. First, even though the KLoSA is a well-designed and nationally representative longitudinal study, the present research only utilized a cross-sectional dataset from the 5th wave. As such, the findings reported here do not imply a causal relationship between religion and depression. Second, it was insufficient to use attendance at religious meetings to measure religious involvement. Private religious practices such as prayer and meditation were unfortunately unavailable in the KLoSA data. Future research should employ multiple measures of religious involvement and longitudinal studies to evaluate possible causal relationship between 
religion and depression. Until then the present study provides a basic understanding of religious variations in depressive symptoms among older Korean adults.

Acknowledgments: This research was supported by Basic Science Research Program through the National Research Foundation of Korea (NRF) funded by the Ministry of Education (2016935435).

Author Contributions: Zong Woo Geem initially planned the study; Jinhee Seomun, Junghyun Park and Hae-Jeung Lee wtore the manuscript; Hae-Jeung Lee and Jinhee Seomun performed statistical analysis; and all authors contributed analysis \& interpretation of data.

Conflicts of Interest: The authors have no conflicts of interest.

If the appendix sections contain a heading then change the argument to "yes".

\section{Appendix A}

\section{A.1. Center for Epidemiologic Studies Short Depression Scale (CES-D 10)}

Below is a list of some of the ways you may have felt or behaved.

Please indicate how often you have felt this way during the past week by checking the appropriate box for each question.

\begin{tabular}{|c|c|c|c|c|}
\hline & $\begin{array}{c}\text { Rarely or None of } \\
\text { the Time } \\
\text { (Less than } 1 \text { Day) }\end{array}$ & $\begin{array}{c}\text { Some or a Little of } \\
\text { the Time } \\
\text { (1-2 Days) }\end{array}$ & $\begin{array}{c}\text { Occasionally or a } \\
\text { Moderate Amount } \\
\text { of Time } \\
\text { (3-4 Days) }\end{array}$ & $\begin{array}{l}\text { All of the Time } \\
\text { (5-7 Days) }\end{array}$ \\
\hline \multicolumn{5}{|l|}{$\begin{array}{l}\text { 1. I was bothered by things that } \\
\text { usually don't bother me. }\end{array}$} \\
\hline \multicolumn{5}{|l|}{$\begin{array}{l}\text { 2. I had trouble keeping my } \\
\text { mind on what I was doing. }\end{array}$} \\
\hline \multicolumn{5}{|l|}{ 3. I felt depressed. } \\
\hline \multicolumn{5}{|l|}{$\begin{array}{l}\text { 4. I felt that everything I did } \\
\text { was an effort. }\end{array}$} \\
\hline \multicolumn{5}{|l|}{ 5. I felt hopeful about the future. } \\
\hline \multicolumn{5}{|l|}{ 6. I felt fearful. } \\
\hline \multicolumn{5}{|l|}{ 7. My sleep was restless. } \\
\hline \multicolumn{5}{|l|}{ 8. I was happy. } \\
\hline \multicolumn{5}{|l|}{ 9. I felt lonely. } \\
\hline 10. I could not get "going." & & & & \\
\hline
\end{tabular}

\section{Appendix B}

Religion section of questionnaire used in the Korean Longitudinal Study on Aging (KLoSA) (translated into English). 

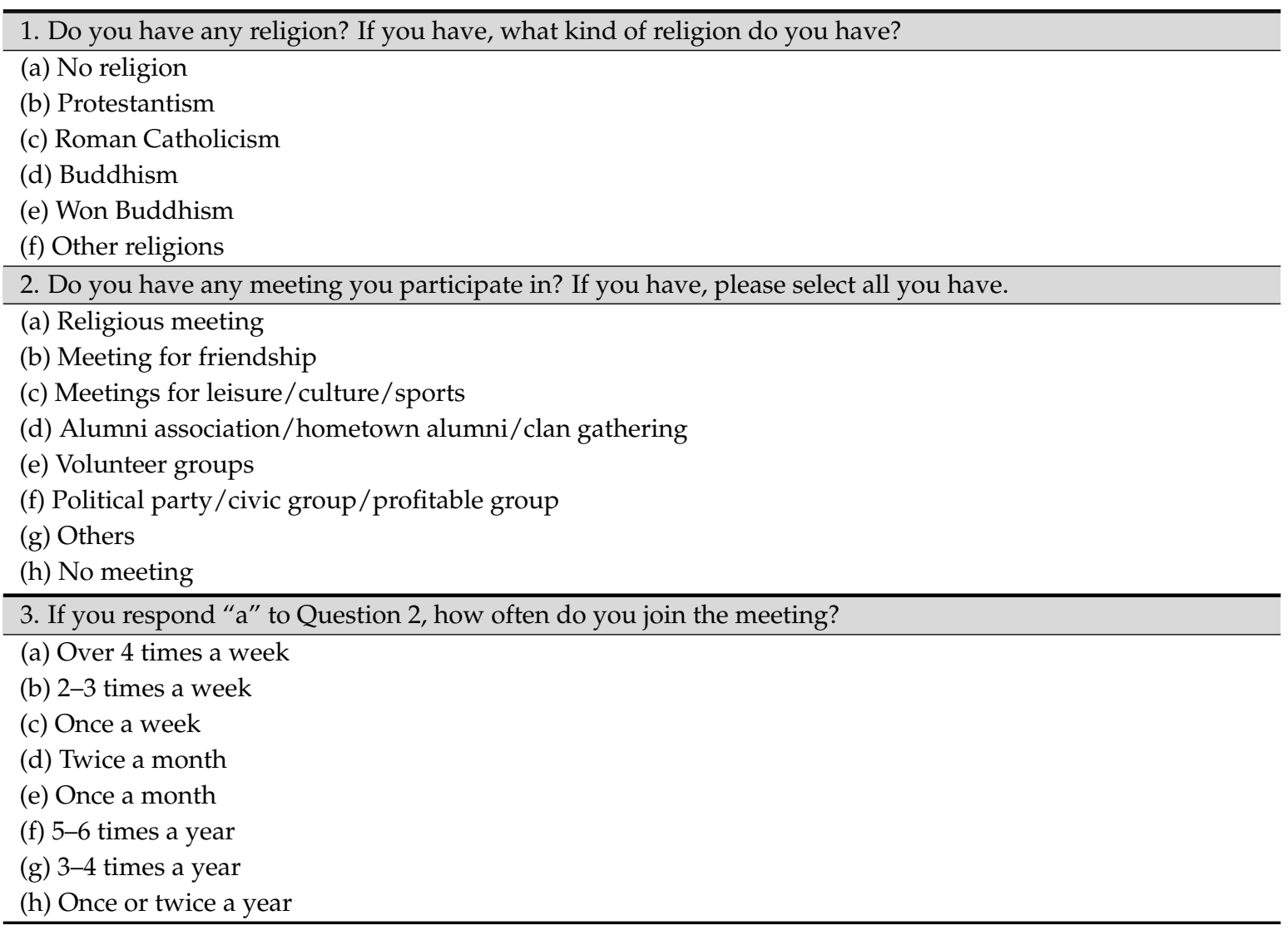

(The 5th Korean Longitudinal Study of Ageing, 2014).

\section{References}

Al-Kandari, Yagoub. 2011. Religiosity, Social Support, and Health among the Elderly in Kuwait. Journal of Muslim Mental Health 6: 81-98. [CrossRef]

Alumkal, Antony W. 1999. Preserving patriarchy: Assimilation, gender norms, and second-generation Korean American evangelicals. Qualitative Sociology 22: 127-40. [CrossRef]

American Psychiatric Association (APA). 2017. What is Depression? Washington: APA.

Baker, Don. 2006. The Religious Revolution in Modern Korean History: From ethics to theology and from ritual hegemony to religious freedom. The Review of Korean Studies 9: 249-75.

Barna, George. 2002. The State of the Church. Basingstoke: Macmillan.

Behere, Prakash B., Anweshak Das, Richa Yadav, and Aniruddh P. Behere. 2013. Religion and mental health. Indian Journal of Psychiatry 55 S2: S187-94. [CrossRef]

Bishwajit, Ghose, Daniel Peter O'Leary, Sharmistha Ghosh, Yaya Sanni, Shangfeng Tang, and Zhanchun Feng. 2017. Association between depression and fruit and vegetable consumption among adults in South Asia. BMC Psychiatry 17: 15. [CrossRef] [PubMed]

Björgvinsson, Thröstur, Sarah J. Kertz, Joe S. Bigda-Peyton, Katrina L. McCoy, and Idan M. Aderka. 2013. Psychometric Properties of the CES-D-10 in a Psychiatric Sample. Assessment 20: 429-36. [CrossRef] [PubMed]

Braam, A. W., P. Van Den Eeden, M. J. Prince, A. T. F. Beekman, S. L. KivelÄ, B. A. Lawlor, A. Birkhofer, R. Fuhrer, A. Lobo, H. Magnusson, and et al. 2001. Religion as a cross-cultural determinant of depression in elderly Europeans: Results from the EURODEP collaboration. Psychological Medicine 31: 803-14. [CrossRef] [PubMed]

Chaaya, M., A. M. Sibai, R. Fayad, and Z. El-Roueiheb. 2007. Religiosity and depression in older people: Evidence from underprivileged refugee and non-refugee communities in Lebanon. Aging \& Mental Health 11: 37-44. [CrossRef] 
Charney, S. Dennis, Charles F. Reynolds, Lydia Lewis, Robert C. Young, Trey Sunderland, George S. Alexopoulos, Dan G. Blazer, Ira R. Katz, Barnett S. Meyers, Patricia A. Arean, and et al. 2003. Depression and bipolar support alliance consensus statement on the unmet needs in diagnosis and treatment of mood disorders in late life. Archives of General Psychiatry 60: 664-72. [CrossRef] [PubMed]

Davidson, Richard J. 2016. Mindfulness-based cognitive therapy and the prevention of depressive relapse: Measures, mechanisms, and mediators. JAMA Psychiatry 73: 547-48. [CrossRef] [PubMed]

Hahn, Cheng-Yi, Mei-Sang Yang, Ming-Jen Yang, Chun-Hua Shih, and Hsin-Yi Lo. 2004. Religious attendance and depressive symptoms among community dwelling elderly in Taiwan. International Journal of Geriatric Psychiatry 19: 1148-54. [CrossRef] [PubMed]

Han, Mi Joon. 2005. Korean Church Future Report. Seoul: Korea Gallop Research Institute, 165 p.

Hayward, R. David, Amy D. Owen, Harold G. Koenig, David C. Steffens, and Martha E. Payne. 2012. Religion and the Presence and Severity of Depression in Older Adults. The American Journal of Geriatric Psychiatry 20: 188-92. [CrossRef] [PubMed]

Helmes, Edward, and Bradley G. Ward. 2017. Mindfulness-based cognitive therapy for anxiety symptoms in older adults in residential care. Aging $\mathcal{E}$ Mental Health 21: 272-78. [CrossRef]

Hodges, Shannon. 2002. Mental Health, Depression, and Dimensions of Spirituality and Religion. Journal of Adult Development 9: 109-15. [CrossRef]

Hsu, Jason. 1996. Multiple Comparisons: Theory and Methods. New York: CRC Press.

Jeon, Hyeon Gyu, Jae Mun Sim, and Kun Chang Lee. 2016. An empirical approach to analyzing effects of disease and activity limit on depression prevalence rate in the elderly depending on stress experience: KNHANES Data Analysis. Korean Journal of Health Education and Promotion 33: 13-22. [CrossRef]

Jung, JaeHoon, Daeyoung Roh, Yoo Sun Moon, and Do Hoon Kim. 2017. The Moderating Effect of Religion on the Relationship between Depression and Suicidal Ideation in the Elderly. The Journal of Nervous and Mental Disease 205: 605-10. [CrossRef] [PubMed]

Kang, Sung-Bong, and Sung-Sook Cho. 2013. Effects of religious activities and faith attitudes on depression and ego-integrity of the elderly. The Journal of the Korea Contents Association 13: 325-46. [CrossRef]

Kim, Andrew Eungi. 2002a. Characteristics of Religious Life in South Korea: A Sociological Survey. Review of Religious Research 43: 291-310. [CrossRef]

Kim, Eungi. 2002b. Religion in Contemporary Korea: Change and Continuity. Available online: http://www. koreafocus.or.kr/design1/layout/content_print.asp?group_id=412 (accessed on 1 July 2017).

Kim, Hong Ryul. 2005. The Study on the Effect of Offering to the Degree of Church Organizational Commitment. Master's thesis, Graduate School of Ministry, Presbyterian University and Theological Seminary, Gwangjin-gu, Seoul, February.

Kim, Chongsuh. 2008. Modernization of Korean Religion and East Asian Religious Mind. Available online: http://s-space.snu.ac.kr/bitstream/10371/3021/1/KimChongsuh_Modernization_of_Korean_ Religion_and_East_Asian_Religious_Mind.pdf (accessed on 1 July 2017).

Kim, Chil-Sung. 2016. Study on the Origin of Religious Exclusivism and Aggressive Evangelism in the Korean Church. Theological Theology 86: 63-96. [CrossRef]

Kim, M. S., and M. J. Park. 2000. A study of religious effect on quality of life in the elderly. Journal of the Korea Gerontological Society 20: 29-47.

Kim, Yong Woo, Sang-Hyuk Lee, Tae Kyou Choi, Shin Young Suh, Borah Kim, Chan Mo Kim, Sung Joon Cho, Myo Jung Kim, Keunyoung Yook, Mi Ryu, and et al. 2009. Effectiveness of mindfulness-based cognitive therapy as an adjuvant to pharmacotherapy in patients with panic disorder or generalized anxiety disorder. Depression and Anxiety 26: 601-6. [CrossRef] [PubMed]

Koenig, Harold G. 2009. Research on Religion, Spirituality, and Mental Health: A Review. The Canadian Journal of Psychiatry 54: 283-91. [CrossRef] [PubMed]

Koenig, Harold G., and Arndt Büssing. 2010. The Duke University Religion Index (DUREL): A Five-Item Measure for Use in Epidemiological Studies. Religions 1: 78-85. [CrossRef]

Koenig, Harold G., Linda K. George, and Bercedis L. Peterson. 1998. Religiosity and remission of depression in medically ill older patients. American Journal of Psychiatry 155: 536-42. [CrossRef] [PubMed]

Koenig, Harold George, Dana King, and Verna B. Carson. 2012. Handbook of Religion and Health. New York: Oup USA.

Korea, Statistics. 2016. Results of the 2015 Population and Housing Census (Population, Household, Religion, and Housing); Seoul: Statistics Korea. 
Kralovec, Karl, Sabine Kunrath, Clemens Fartacek, Eva-Maria Pichler, and Martin Plöderl. 2017. The Gender-Specific Associations between Religion/Spirituality and Suicide Risk in a Sample of Austrian Psychiatric Inpatients. Suicide and Life-Threatening Behavior. Available online: http:/ / onlinelibrary.wiley. com/doi/10.1111/sltb.12349/pdf (accessed on 1 July 2017).

Krause, Neal. 2006. Exploring the Stress-Buffering Effects of Church-Based and Secular Social Support on Self-Rated Health in Late Life. The Journals of Gerontology: Series B 61: S35-43. [CrossRef]

Krause, Neal, Berit Ingersoll-Dayton, Jersey Liang, and Hidehiro Sugisawa. 1999. Religion, Social Support, and Health among the Japanese Elderly. Journal of Health and Social Behavior 40: 405-21. [CrossRef] [PubMed]

Kuyken, Willem, Fiona C. Warren, Rod S. Taylor, Ben Whalley, Catherine Crane, Guido Bondolfi, Rachel Hayes, Marloes Huijbers, Helen Ma, Susanne Schweizer, and et al. 2016. Efficacy of mindfulness-based cognitive therapy in prevention of depressive relapse: An individual patient data meta-analysis from randomized trials. JAMA Psychiatry 73: 565-74. [CrossRef] [PubMed]

Kwon, Victoria Hyonchu, Helen Rose Ebaugh, and Jacqueline Hagan. 1997. The structure and functions of cell group ministry in a Korean Christian church. Journal for the Scientific Study of Religion 36: 247-56. [CrossRef]

Lee, Shinsook, and Kyeongju Lee. 2002. The Stress, Social Support and Psychological Well-being of the Elderly. Journal of the Korea Gerontological Society 22: 1-20.

Levin, Jeffrey S., and Linda M. Chatters. 1998. Religion, Health, and Psychological Well-Being in Older Adults. Journal of Aging and Health 10: 504-31. [CrossRef] [PubMed]

Li, Shanshan, Olivia I. Okereke, Shun-Chiao Chang, Ichiro Kawachi, and Tyler J. VanderWeele. 2016. Religious Service Attendance and Lower Depression among Women-a Prospective Cohort Study. Annals of Behavioral Medicine 50: 876-84. [CrossRef] [PubMed]

Maxwell, Lindsay, and Elsie Duff. 2016. Mindfulness: An Effective Prescription for Depression and Anxiety. The Journal for Nurse Practitioners 12: 403-9. [CrossRef]

McFarland, Michael J. 2010. Religion and Mental Health Among Older Adults: Do the Effects of Religious Involvement Vary by Gender? The Journals of Gerontology Series B: Psychological Sciences and Social Sciences 65B: 621-30. [CrossRef] [PubMed]

Min, Pyong Gap. 2014. Development of Protestantism in South Korea: Positive and Negative Elements. Asian American Theological Forum. Available online: https://aatfweb.org/2014/10/31/development-ofprotestantism-in-south-korea-positive-and-negative-elements / (accessed on 1 July 2017).

Ministry of Health and Welfare (MHW). 2012. One among 6 Adults Experiences Mental Health Problem in 2011; Sejong-si: MHW.

Ng, Guan Chong, Salina Mohamed, Ahmad Hatim Sulaiman, and nor Zuraida Zainal. 2017. Anxiety and depression in cancer patients: The association with religiosity and religious coping. Journal of Religion and Health 56: 575-90. [CrossRef] [PubMed]

O'Connor, Brian P., and Robert J. Vallerand. 1990. Religious Motivation in the Elderly: A French-Canadian Replication and an Extension. The Journal of Social Psychology 130: 53-59. [CrossRef] [PubMed]

Park, Jisung, Soonhee Roh, and Younsook Yeo. 2012a. Religiosity, Social Support, and Life Satisfaction among Elderly Korean Immigrants. The Gerontologist 52: 641-49. [CrossRef] [PubMed]

Park, Jong-Ik, Jin Pyo Hong, Subin Park, and Maeng-Je Cho. 2012b. The Relationship between Religion and Mental Disorders in a Korean Population. Psychiatry Investigation 9: 29-35. [CrossRef] [PubMed]

Penninx, Brenda W. J. H., Theo van Tilburg, Didi M. W. Kriegsman, Dorly J. H. Deeg, A. Joan P. Boeke, and Jacques Th M. van Eijk. 1997. Effects of Social Support and Personal Coping Resources on Mortality in Older Age: The Longitudinal Aging Study Amsterdam. American Journal of Epidemiology 146: 510-19. [CrossRef] [PubMed]

Radloff, Lenore Sawyer. 1977. The CES-D Scale. Applied Psychological Measurement 1: 385-401. [CrossRef]

Rasic, Daniel, Steve Kisely, and Donald B. Langille. 2011. Protective associations of importance of religion and frequency of service attendance with depression risk, suicidal behaviours and substance use in adolescents in Nova Scotia, Canada. Journal of Affective Disorders 132: 389-95. [CrossRef] [PubMed]

SAS. 1999. Chapter 30 The GLM Procedure. In SAS/STAT User's Guide. version 8; Cary: SAS.

Seomun, Jinhee. 2010. A Study on the Relation between Religion and Depression/Quality of Life for the Elderly People. Church Social Work 12: 67-95.

Smith, Timothy B., Michael E. McCullough, and Justin Poll. 2003. Religiousness and depression: Evidence for a main effect and the moderating influence of stressful life events. Psychological Bulletin 129. [CrossRef] 
Wink, Paul, Michele Dillon, and Britta Larsen. 2005. Religion as Moderator of the Depression-Health Connection. Research on Aging 27: 197-220. [CrossRef]

Won, Mi-Ra, Me-Sun Ahn, and Yun-Jung Choi. 2017. Factors Associated with Perceived Depression of Korean Adults: Secondary Data from the Korean Community Health Survey. Community Mental Health Journal 53: 288-96. [CrossRef] [PubMed]

You, Kwang Soo, Hae-Ok Lee, Joyce J. Fitzpatrick, Susie Kim, Eiji Marui, Jung Su Lee, and Paul Cook. 2009. Spirituality, Depression, Living Alone, and Perceived Health among Korean Older Adults in the Community. Archives of Psychiatric Nursing 23: 309-22. [CrossRef] [PubMed]

(C) 2017 by the authors. Licensee MDPI, Basel, Switzerland. This article is an open access article distributed under the terms and conditions of the Creative Commons Attribution (CC BY) license (http:/ / creativecommons.org/licenses/by/4.0/). 